\title{
ХАРАКТЕРИСТИКА ДІЯЛЬНОСТІ ЗОВНІШНІХ ПІЛОТІВ БЕЗПІЛОТНИХ АВІАЦІЙНИХ КОМПЛЕКСІВ ТА ЇХ ПРОФЕСІЙНО ВАЖЛИВІ ЯКОСТІ: ТЕОРЕТИКО-ПРАКТИЧНІ АСПЕКТИ
}

\author{
В.В. Кальниш ${ }^{1}$, А.В. Швець ${ }^{1}$, С.М. Пашковський ${ }^{2}$ \\ 1 Украӥнська військово медична академія, м. Київ, Україна \\ 2 Військово-медичний клінічний центр Центрального регіону, м. Вінниця, Україна
}

Актуальність. Наявна інформація щодо професійних вимог до операторів безпілотних авіаційних комплексів (БпАК) та їх психофізіологічних якостей, що дозволяють виконувати керування цими комплексами в звичайних та екстремальних ситуаціях, $\epsilon$ обмеженою, розрізненою та несистематизованою. Всі ці причини стимулюють детальну розробку та уточнення переліку професійно важливих якостей та психофізіологічних критеріїв професійної придатності операторів БпАК потрібних для успішного виконання своєї діяльності.

Метою даної роботи $\epsilon$ пошук у сучасній літературі переліку професійно важливих якостей операторів БпАК та адекватних методів проведення професійного психофізіологічного відбору.

Матеріали та методи. 3 використанням методів системного, бібліосемантичного та ретроспективного аналізу вивчено наукові публікації щодо переліку професійно важливих якостей операторів БпАК та адекватних методів проведення професійного психофізіологічного відбору. Для цього здійснено пошук доступних джерел інформації з 1982 по 2020 роки, які стосувались характеристик професійної діяльності операторів безпілотних літальних апаратів, безпілотних авіаційних комплексів (систем), дронів. Вивчали характеристики діяльності зовнішніх пілотів безпілотних авіаційних комплексів та їх професійно важливі якості. На основі наявних даних було узагальнено класифікацію внутрішніх та зовнішніх шкідливих чинників в професійній діяльності особового складу пілотів БпАК та характеристики їх професійно важливих якостей, що були зазначені у доступних публікаціях.

Результати. Проведено попередній аналіз літературних даних щодо визначення професійної придатності операторів БпАК. Запропоновано узагальнений перелік психологічних та психофізіологічних показників, що можуть застосовуватися для визначення ступеня професійної придатності операторів. Цей перелік може використовуватися для визначення критеріїв професійної придатності. Світовий досвід показує, що складна та відповідальна робота оператора БпАК потребує не тільки первинного відбору до цієї роботи, але й постійного моніторингу психофізіологічних характеристик оператора для збереження його здоров'я, забезпечення високої працездатності та надійності при виконанні бойових завдань, підвищення професійного довголіття.

Висновки. Проведено аналіз професійної діяльності операторів безпілотних авіаційних комплексів (БпАК) та визначено основні функціональні обов'язки та стрес-навантаження цих осіб. Запропоновано класифікацію внутрішніх та зовнішніх шкідливих чинників в професійній діяльності особового складу пілотів БпАК. Виявлено та запропоновано перелік психологічних та психофізіологічних професійно важливих якостей пілотів БпАК, що забезпечують успішність виконання професійної діяльності, та $\epsilon$ необхідними для проведення професійного відбору персоналу з керування безпілотними авіаційними комплексами $і$ моніторингу їх психофізіологічних якостей, а також якості, що перешкоджають ефективності професійної діяльності. Визначено комплекс методичних засобів, використання яких сприятиме проведенню професійного психофізіологічного відбору операторів БпАК.

Ключові слова: професійно важливі якості, професійна діяльність, зовнішні пілоти, безпілотний авіаційний комплекс.

Вступ. Сьогодення характеризується все ширшим застосуванням постійно удосконалюваної автоматизованої безпілотної техніки [1]. Однією 3 вагомих причин застосування безпілотних авіаційних комплексів (БпАК) є велике прагнення людини не тільки позбавитися ризиків для свого життя, але й віддалитися та 3 допомогою технічних засобів відгородитися від наслідків своїх дій, в тому числі і таких, як вбивство. Безпілотні авіаційні комплекси $є$ таким видом авіації, що найбільш активно розвивається в світі. Робочі місця зовнішніх пілотів (операторів) БпАК облаштовані різноманітними складними системами відображення інформації та управління, 3 урахуванням тривалості та змісту можливих завдань [2]. На думку Петренка О.В. подальший розвиток автоматизації керуванням безпілотних літальних апаратів буде спрямований на розробку потужного інформаційного забезпечення діяльності людини, для підвищення потенціалу ї̈ евристичних 
можливостей щодо прийняття рішень в умовах невизначеності [2].

Безпілотні літальні апарати, за деяким виключенням, повністю не позбавлені можливості керування людиною цим пристроєм. Вони можуть керуватися людиною дистанційно з виконанням багатьох елементів, властивих елементам керування безпосередньо льотчиком. Ця тотожність в забезпеченні управління літаками та безпілотними літальними комплексами навела на думку, що професійно важливі якості льотчика та пілота БпАК є аналогічними. Але світовий досвід показав, що існують деякі значимі розбіжності в роботі цих фахівців.

По-перше, надавтоматизована техніка, особливо у військовій справі, $€$ могутнім фактором збереження здоров'я й життя військовослужбовців. Якщо льотчик безпосередньо відчуває небезпеку життю чи здоров'ю завдяки впливу шкідливих факторів середовища, то оператор БпАК в багатьох випадках позбавлений цих шкідливих впливів.

По-друге, процеси, які протікають в сучасному бої, мають дуже швидкий перебіг змін різноманітних значущих подій, що вимагає від дистанційно керуючих цими процесами операторів особливих психофізіологічних якостей для успішного досягнення потрібних результатів. Справа в тому, що дистанційне керування не дозволяє людині безпосередньо отримувати додаткову інформацію 3 неінструментальних джерел. Тому обсяг інформації, що надходить, обмежується тільки наявними технічними можливостями, що веде до зміни відношення до результатів прийняття відповідальних рішень, зокрема, до небезпек, викликаних виконанням польотних завдань.

По-третє, значна тривалість процесу керування БпАК вимагає від оператора постійно тримати концентрацію уваги оператора на високому рівні, а також витримувати довготривалу однорідну діяльність.

По-четверте, як показав досвід застосування БпАК в бойових умовах, вони дозволяють не тільки знизити втрати особового складу, але й підвищують ефективність застосування озброєння та забезпечують високу якість дій військових формувань [3]. Автори підкреслюють, що складність керування БпАК та велика різноманітність завдань реалізованих 3 їх допомогою, визначають надширокий спектр вимог до професійно важливих якостей цих операторів. Тому біля 50\% невдалих польотів БпАК пов'язують з людським фактором $[4,5]$.
Перевагою в діяльності оператора БпАК перед пілотом літака $\epsilon$ його більша психологічна розкутість завдяки тому, що він здійснює керування комплексом на відстані, де немає загрози власного життя. Але комплексність і складність його професійних обов'язків (обов'язки штурмана, пілота тощо) накладають негативний відбиток на функціональний стан оператора та сприяють зменшенню емоційних, інтелектуальних та фізичних ресурсів [6].

Правилами виконання польотів безпілотними авіаційними комплексами державної авіації України, затвердженими наказом Міністерства оборони України від 08 грудня 2016 року № 661 [8] визначено, що зовнішнім пілотам (операторам), які входять до складу зовнішнього екіпажу, надається право на виконання польотів за умови отримання відповідного допуску та придатності до польотів за висновком лікарсько-льотної комісії, крім зовнішніх пілотів (операторів) БпАК 1 класу мікро.

Разом з тим, положенням про лікарськольотну експертизу в державній авіації України, затвердженим наказом Міністерства оборони України від 20 листопада 2017 року № 602 [9], згадана експертиза, як складова військоволікарської експертизи, визначає придатність осіб не тільки до виконання польотів, але й керування БпАК за показниками стану здоров'я, фізичного розвитку і професійно важливих психофізіологічних якостей. Однак, умови професійної діяльності та професійно важливі психофізіологічні якості льотчиків i операторів БпАК відрізняються, що потребує формалізованої оцінки вимог, які висуває професія до стану здоров'я та психофізіологічних якостей осіб 3 метою якісного i безпечного виконання ними обов'язків за призначенням.

В сучасній літературі наводяться дані про зміст діяльності та дано характеристики деяких застосовуваних в Україні та за кордоном безпілотних літальних апаратів [7]. Зроблено висновок щодо доцільності застосування професійного відбору до операторів БПАК внаслідок складності виконуваних ними завдань. Але наявна інформація щодо професійних вимог до операторів БпАК та їх психофізіологічних якостей, що дозволяють виконувати керування цими комплексами в звичайних та екстремальних ситуаціях, $€$ обмеженою, розрізненою та несистематизованою. Всі ці причини стимулюють детальну розробку та уточнення переліку професійно 
важливих якостей та психофізіологічних критеріїв професійної придатності операторів БпАК потрібних для успішного виконання своєї діяльності.

Метою даної роботи є пошук в сучасній літературі переліку професійно важливих якостей операторів БпАК та адекватних методів проведення професійного психофізіологічного відбору.

Матеріали та методи дослідження. 3 використанням методів системного, бібліосемантичного та ретроспективного аналізу вивчено наукові публікації щодо переліку професійно важливих якостей операторів БпАК та адекватних методів проведення професійного психофізіологічного відбору. Для цього здійснено пошук доступних джерел інформації з 1982 по 2020 роки, які стосувались характеристик професійної діяльності операторів безпілотних літальних апаратів, безпілотних авіаційних комплексів, безпілотних авіаційних систем, дронів. Вивчали характеристики діяльності зовнішніх пілотів безпілотних авіаційних комплексів та їх професійно важливі якості. На основі наявних даних було узагальнено класифікацію внутрішніх та зовнішніх шкідливих чинників в професійній діяльності особового складу пілотів БпАК та характеристики їх професійно важливих якостей, що були зазначені у доступних публікаціях.

Результати дослідження. Згідно 3 відповідним наказом МО України [8] до функцій зовнішнього пілота (оператора) безпілотного авіаційного комплексу) командира зовнішнього екіпажу безпілотного авіаційного комплексу відносяться: своєчасне і точне виконання польотного завдання зовнішнім екіпажем з дотриманням встановлених заходів безпеки (готуватися до польоту відповідно до польотного завдання та розробляти конкретні заходи безпеки до нього); керування підготовкою та оцінювати готовність членів зовнішнього екіпажу до виконання польотного завдання; готувати зовнішній екіпаж до дій в особливих випадках (ситуаціях) у польоті; доповідати своєму прямому начальнику у разі, якщо будь-хто з членів зовнішнього екіпажу вважає польотне завдання непосильним для себе або не впевнений $\mathrm{y}$ безпеці його виконання, і вимагати його заміни; приймати БпАК перед польотом; контролювати розміщення на борту БпАК та кріплення (швартування) вантажів (озброєння, техніки та спецобладнання); приймати рішення на виконання польоту, зліт та посадку; керувати роботою членів зовнішнього екіпажу під час виконання польоту БпАК; керувати під час польоту БпАК відповідно до польотного завдання; вести орієнтування під час керування БпАК; приймати рішення на продовження (припинення) польоту БпАК у разі ускладнення повітряної (наземної) обстановки; бути обачним, не допускати небезпечного зближення БпАК 3 іншими літальними засобами i наземними перешкодами; проводити розбір польотів 3 екіпажем БпАК тощо.

Зовнішній пілот (оператор БпАК): приймає остаточне рішення про виконання польоту, політ і посадку БпАК, зливання в польоті пального, скидання вантажу, зміну плану і режиму польоту, припинення польоту і посадку БпАК на запасному аеродромі чи вимушену посадку за межами аеродрому; вживає всіх необхідних заходів, у тому числі примусових, до осіб, які своїми діями створюють загрозу особовому складу і не підкоряються його розпорядженням; змінює маршрут та режим польоту БпАК; приймає рішення про припинення польоту і виконує посадку БпАК на аеродромі; керує діями зовнішнього екіпажу БпАК у межах своєї компетенції у разі вимушеної посадки БпАК до передання своїх повноважень керівнику 3 ліквідації надзвичайної ситуації тощо.

Як видно з наведеного оператор БпАК в своїй роботі поєднує функції керівника та оператора-спостерігача. Останнє є суттєвою частиною професійної діяльності цього фахівця. Оператор БпАК - це операторспостерігач, який відокремлений від об'єкта управління і в своїй діяльності орієнтується на сигнали, надіслані від окремих компонентів БпАК. Принциповою різницею між роботою льотчика та оператора БпАК $\epsilon$ те, що у останнього $є$ тільки опосередкований зв'язок (постійний чи періодичний, який може перериватися за технічних причин) з БпАК через існуючі канали комунікації [10]. Тому однією з важливих проблем, яка постає перед оператором БпАК $€$ трудність уникання 3 перешкод, які можуть раптово виникнути перед БпАК, що здійснює політ [11]. В цьому випадку швидкість вироблення рішення при виникненні непередбачуваних ситуацій у оператора БпАК повинна бути достатньо високою. Американським дослідником К. Вараичем доведено, що особи які здійснюють ефективне пілотування літака на віртуальних стимуляторах виконують роль операторів БпАК краще, ніж бойові льотчики [12]. Було 
з'ясовано, що пілоти 3 великим досвідом професійної діяльності роблять більше помилок при управлінні, ніж особи, які добре володіють комп'ютерним управлінням літальними апаратами.

При управлінні БпАК можуть з'являтися особливі психотравмуючі ситуації, які $\epsilon$ причиною великих психологічних навантажень [13]. Автори підкреслюють, що для ослаблення цих навантажень оператор БпАК повинен володіти високою психологічною стійкістю. Крім того, його поведінка в бойових ситуаціях в чималому ступені залежить від типу темпераменту.

Таким чином, низкою авторів констатується, що 3 допомогою БпАК виконується кілька бойових завдань: забезпечення в реальному режимі часу передачі візуальної інформації, яка потрібна для визначення нерухомих і рухомих цілей; відстеження пересувань противника; оцінка його сил і озброєнь; виявлення і знищення схованок зі зброєю; отримання інформації для управління і організації повітряного прикриття наземних сил; забезпечення безпеки пересування своїх військ; стеження за бойовиками i/або їх знищення, оцінка збитку, нанесеного противнику тощо [14]. Разом з цим, безпосереднє використання БпАК значно відсторонює людину від певних результатів їі діяльності, що негативно впливає на такі необхідні в військовій праці чесноти: відвагу, вірність, честь і милосердя [15].

В огляді літератури, зробленому A.I. Першлевичем та спіавт. [6] виокремлені деякі важливі аспекти діяльності оператора БпАК. Авторами відзначено, що великі інформаційні навантаження знижують у операторів БпАК працездатність, увагу, гнучкість мислення, швидкість реакції і морально-психологічну стійкість, що призводить до появи помилок і, в кінцевому рахунку, зриву виконання польотних завдань. Особливо значні психотравмуючі проблеми, пов'язані 3 роздільною здатністю відео і фотокамер БпАК і управлінням в умовах наявності суперечливих розвідувальних даних, висока відповідальність за знищення живої сили противника, що викликає у людини негативно забарвлені емоції і зменшують психофізіологічні резерви організму. Ще одним комплексом умов, що ускладнює діяльність оператора БпАК, є: невідповідні можливостям БпАК метеорологічні обставини; відмова технічних засобів, що забезпечують політ; втрата зв'язку між членами команди управління БпАК; небезпечне зближення 3 іншими повітряними апаратами і наземними перешкодами, що зумовлює перехід роботи оператора БпАК в режим гострого дефіциту часу i інформації. Якщо противник має можливість підключитися до каналу зв'язку БпАК у оператора може виникнути страх за своє життя так як у супротивника з'являється можливість виявити пункт управління польотом і завдати по ньому удар.

Окремою важливою задачею $\epsilon$ аналіз керуючих рухів оператора БпАК, який характеризує функціональну надійність його професійної діяльності і ефективність виконання її завдань, а також дозволяє забезпечити адекватне урахування психофізіологічного стану i резервних можливостей оператора БпАК при реалізації функцій управління польотом [16].

Найважливішою ланкою у формуванні виконавчих дій оператора є образ польоту, образ ситуації, образ дій (зокрема, руховий образ). Як вказували Н.Д.Завалова і співавт. «Образ польоту являє собою систему психічної регуляції дій льотчика» [17] як базовий компонент психічного відображення. «Образ польоту включає завдання і цілі, які стоять перед льотчиком, систему знань про об'єкт управління, систему рухових програм, що реалізуються в польоті. При виконанні конкретних дій в образі польоту на перший план виступає (в залежності від умов польоту і мети, яку ставить льотчик) один із трьох компонентів: образ просторового положення, почуття літака, сприйняття приладового відображення (або приладової моделі) [17]. Всі три зазначених компоненти 3 урахуванням специфіки їх роботи, в якійсь мірі, присутні у оператора БпАК.

Побудована Н.Д.Гордєєвою функціональна модель предметної дії, уточнює деталі формування образу польоту, враховує такі компоненти програмування дій: «предметна ситуація (рухове завдання, мотив); інсталяційний сигнал; поточні екстрені сигнали; поточні екстрені команди; зміна предметної ситуації; інформація 3 навколишнього середовища; інформація зі схем пам'яті; актуалізація образу; інформація, релевантна руховій задачі; формування програми, плану дії; схема дії; деталізація програми дії; моторні команди; поточна інформація від руху; поточний корекційний сигнал; випереджуючий зворотний зв'язок; корекційні моторні команди; кінцева інформація від руху; зміна предметної ситуації 
(інформація для образу ситуації і способу дії); зміна предметної ситуації (інформація для полімодального аферентатора); кінцевий результат; інформація в схеми пам'яті» [18]. Автор зазначає, що «функціональна модель предметної дії придатна для опису багатьох різних форм і видів людської дії, наприклад, таких як дискретне i безперервне спостереження, повільна і балістична дія, що формується i заучується, виконавча i спонукальна дія - перцептивна, регулярна i екстрена». Визначені компоненти формування образу дій, програмування дій доцільно використовувати при виявленні професійно важливих якостей оператора БпАК.

М.A. Кремінь та В.М. Водлозеров стверджують, що динамічний образ «являє собою відображення детермінованою або ймовірнісною послідовністю координат (або параметрів) керованого процесу, що співвідносяться 3 апріорно заданими (або близькими до них) значеннями часу» [19]. Аналіз успішності майбутніх льотчиків за параметрами їх стратегії стеження дозволив В.М. Водлозерову і С.Г. Тарасову встановити, що найменша необхідна кількість тренувань до першого самостійного польоту спостерігалася у курсантів 3 випереджувальною стратегією стеження, а найбільша їх кількість - у курсантів 3 запізнілою стратегією (ці курсанти відраховуються за параметром льотної неуспішності в два рази частіше, ніж курсанти 3 попереджувальною стратегією) [19]. Майбутні льотчики зі змішаною стратегією займають проміжне положення. Курсанти 3 випереджувальною стратегією при виконанні стеження ведуть себе в «польоті» вільно, плавно, рівномірно і без різких рухів впливають на ручку управління. Їм легко вдається засвоювати елементи управління, своєчасно виявляти відхилення в режимі «польоту» в екстремальних умовах діяльності, а також самостійно їх усувати. Навпаки, у курсантів 3 запізнілою стратегією управління навички «водіння» формуються повільно, керуючі рухи у них характеризуються нерівномірністю, часом, імпульсивністю, їх реакції, як правило, запізнілі. Таким чином, застосовувана людиною стратегія управління може грати значну роль в формуванні успішності діяльності оператора.

При управлінні рухомим об'єктом створюються необхідні умови для формування завершеної, логічною форми образу, який в гештальтпсихології називається прегнантність [20]. В процесі побудови такого образу виникають об'єктивні психофізіологічні труднощі (сприйняття, створення моделі процесу вирішення проблемної ситуації, вироблення програми дій, прийняття рішень, емоційного реагування на складену ситуацію, подолання поведінкових шаблонів і ін.), які пов'язують наявними у людини рефлексивними обмеженнями. Для оцінки таких рефлексивних обмежень розроблена методика визначення рівня розвитку рефлексивної компетентності [21].

Для створення і використання образу дій необхідне залучення функції уваги. У літературі вказується, що увага характеризується нестійкою рівновагою [22]. Причому при низькому рівні активації організму можливий розподіл уваги на різні види діяльності, а при підвищенні цього рівня увага прагне до концентрації і іï розподіл на інші завдання ускладняється оскільки система уваги має обмежені можливості і ресурси. Універсальним механізмом вибіркового сприйняття i формування рухового акту є вибіркова увага. Система вибіркової уваги $\epsilon$ першою i найважливішою ланкою адаптаційної реакції організму, яка включає в себе емоційні та нейрогуморальні компоненти [23]. Вибіркова увага визначається як процес встановлення в поточний момент часу зв'язку між наявним досить обмеженим набором повідомлень зовнішнього і внутрішнього середовища організму i лімітованими можливостями рухових підсистем, які формують поведінкові акти [22]. Як вказують М.Ф. Суворов та О.П. Таіров, обмеження функціонування вибіркової уваги пов'язані з можливістю використання кінцевих ресурсів нервової системи, якістю перероблюваних сенсорних сигналів, лімітованими властивостями пам'яті та рухливості нервових процесів. Для оцінки ефективності вибіркової уваги часто застосовують тести: на тривале підтримання функції (CPT), оцінки змінних уваги (TOVA) i завдання візуальної організації Хупера (VOT).

Деякі автори наводять перелік інших психофізіологічних професійно важливих якостей: здатність і готовність до швидкого і точного засвоєння нових знань, формування нових навичок і умінь в постійно мінливих умовах; здатність виконувати зобов'язання і контролювати прийняті рішення в стандартних i нестандартних ситуаціях; здатність регулярно і точно виконувати норми, правила, встановлені в колективі; здатність досягати поставлених цілей, виконувати завдання, підпорядковуючи цьому свої дії; 
здатність виконувати роботу в заданих умовах протягом певного відрізка часу; здатність швидко i точно виконувати доручення відповідно до заданих стандартів, правил; здатність зберігати внутрішній спокій, ефективно взаємодіяти з людьми і працювати в умовах впливу факторів, несприятливих для життя і діяльності [10]. Інші, зокрема, В.М. Кичак i спіавт. професійно важливими характеристиками вважають: стійку увагу; стресостійкість; комунікативні якості; готовність до навчання; постійність і точність під час роботи; відповідальність; зібраність [25]. Було також встановлено, що для проведення професійного відбору операторів БпАК важливо прийняти до уваги їх особистісні риси з застосуванням опитувальника NEO [26, 27]. Зустрічається перелік особистісних якостей, які сприяють ефективній роботі 3 БпАК: мобільність, психічне здоров'я, відповідальність, дисциплінованість, цілеспрямованість, старанність, стресостійкість і динамічне мислення під яким розуміють здатність і готовність до швидкого і точного засвоєння нових знань, формування нових навичок і умінь в постійно мінливих умовах [10]. Всі надані переліки повністю не співпадають, a, скоріше доповнюють один одного. Але з них можна побачити, що фахівець 3 управління БпАК повинен мати такий багатоманітний комплекс особистісних якостей, оцінка якого потребує ретельного підходу до професійного відбору цих фахівців. Такий пильний відбір (це видно з об’ємного переліку професійно важливих якостей) потребує досить великого часу для проведення психофізіологічних досліджень. Ця вимога дуже часто викликає спротив, як у керівників військових частин, так і серед тестованих операторів.

У публікації Т.Є. Ударцевої [7] 3 посиланням на відповідний наказ МОЗ України [28] наведено перелік професійно важливих якостей, який доцільно застосовувати для проведення професійного відбору операторів БпАК. До цього переліку потрібно відноситись з певною пересторогою за таких міркувань. Поперше, він був затверджений в 1994 році. За декілька десятирічь, що минули 3 того часу теорія i практика професійного відбору корінним чином змінилась і тому застосування цього документу потрібно проводити з певною пересторогою. По-друге, визначений перелік професійно важливих якостей відноситься до авіадиспетчерів та диспетчерів по управлінню рухом залізничного транспорту, а також до робіт, пов'язаних 3 управлінням наземним, підземним, повітряним та водним транспортом. В той час, коли розроблявся цей документ, безпілотні літальні апарати використовувались дуже епізодично і тому специфіка цієї роботи не була врахована. Потретє, пункти «увага» та «швидкість переключення уваги» перекриваються оскільки переключення уваги $\epsilon$ однією 3 характеристик уваги. По-четверте, пункти «емоційна стійкість та почуття тривоги» та «стійкість до впливу стресів» тотожні за своїм змістом. По-п'яте, пункт «втома» не може бути використаний при професійному відборі оскільки не визначено в яких умовах та за який час потрібно оцінювати втому. Крім того, при проведенні первинного професійного відбору ніякої втоми ще немає. Все перелічене викликає певне побоювання щодо виконання рекомендації використовувати наведений перелік для здійснення професійного відбору операторів БПАК.

Фундаментальна робота B.I. Пасічника та В.С. Афанасенка [3] більш повно розкриває різні сторони проблеми професійного відбору операторів БпАК. За рейтинговими оцінками вони визначили низку професійно важливих для цієї професії психологічних та психофізіологічних якостей в такій послідовності: спроможність тривалий час зберігати стійку увагу та розподіляти її під час виконання декількох функцій, завдань; розвиненість пам'яті та просторової уяви; здатність до навчання, розвиненість та гнучкість процесів мислення; спрямованість на досягнення професійного успіху, сумлінне виконання службового обов'язку; емоційна стійкість, врівноваженість і самовладання у разі виникнення напружених ситуацій; точність і координованість рухів; адаптивність, здатність до саморегуляції та самоконтролю; висока працездатність, уміння витримувати значні фізичні навантаження; уміння висловити думку у словах чітко і лаконічно та продуктивно спілкуватися в емоційно напружених ситуаціях. Додатково можна добавити таку якість, як поріг індивідуальної стійкості нервової системи, за яким настає зрив у її функціонуванні [29].

У роботі B.I. Пасічника та В.С. Афанасенка дається перелік провідних професійно важливі якості оператора БпАК та діагностичні методи та методики, які використовуються для оцінки цих якостей. Також наведено розгорнуту «Психологічну карту успішного оператора БПАК тактичних класів», що дає змогу більш 
системно проводити професійний відбір. Проте в статті В.І.Пасічник та В.С. Афанасенко чомусь змішуються поняття медичного та психофізіологічного відбору в одну категорію, що $\epsilon$ недоцільним 3 огляду на напрям отриманих знань фахівцями лікарями та лікарями психофізіологами. Справа в тому, що психофізіологія вивчає фізіологічні основи і механізми цілісних форм психічної діяльності і поведінки людини у взаємодії нейрофізіологічними процесами, а також роль біолого-гігієнічних факторів, в тому числі властивостей нервової системи, в реалізації психічної діяльності. Зовсім іншою справою займається лікар: він аналізує хвороби центральної і периферичної нервової системи та інших органів. Під впливом екстремальних факторів зовнішнього середовища можуть порушуватися функції всіх систем і органів людського організму, відновлення функціонування яких $\epsilon$ важливою задачею лікаря. 3 викладеного видно, що медичний та психофізіологічний відбір мають свої специфічні задачі та методи їх вирішення. Тому медичний і психофізіологічний відбір потрібно розглядати окремо.

У докладному літературному огляді 3 англомовних джерел (США) Ю.Ю. Першин наводить дані, згідно з якими 14-26\% операторів БпАК мали симптоми емоційного вигорання, у 7-17\% виникало почуття цинізму, у 4.3\% операторів виявилися клінічно значущі симптоми ПТСР, а $32 \%$ операторів, у яких не виявлено симптомів ПТСР, скаржилися на проблеми зі сном [30]. Вказується, що низкою авторів виділено кілька значущих стресорів, що впливають на операторів БпАК, дія цих стресорів призводить до формування у них емоційного вигорання: тривалість тижневого робочого часу, часта зміна режимів праці та відпочинку, труднощі з проїздом на роботу і навпаки, незручне робоче місце та незадовільний температурний режим, постійна концентрація уваги на аудіо та відеоінформації, необхідність вирішення безлічі завдань за обмежений проміжок часу при проведенні розвідки спостереження, стеження в процесі ведення бойових дій. При цьому бойовими стресорами служать: точність наведення на об'єкт, знищення ворожих комбатантів, можливість ураження дружніх сил і цивільних осіб, вплив на оператора відеоматеріалів, які фіксують факти знищення комбатантів, прийняття рішення про виявлення противника 3 одночасним захистом дружніх сил i цивільного населення. Перелічені впливи на організм оператора БпАК призводять до поступового розвитку у них емоційного вигорання різного ступеня, що суттєво заважає ефективному виконанню бойових завдань.

На основі наявних в психології, фізіології та гігієні праці класифікаціях, нами було запропоновано класифікацію шкідливих чинників в професійній діяльності операторів БпАК, яка наведена у таблиці 1.

Тут, поряд із відомими чинниками, зміст і дія яких очевидний, висвітлені специфічні, так звані “незвичні" шкідливі чинники (електромагнітне випромінювання, внутрішній мікроклімат (освітлення, температурні фактори тощо), моторна депривація). Фактори, які пов'язані 3 власною структурою інформаційного потоку. Фактори комунікабельності).

Обговорення. Проведений огляд доступних літературних джерел дозволяє попередньо сформувати перелік психологічних та психофізіологічних професійно важливих якостей операторів БпАК, необхідних при прийнятті рішення щодо придатності до виконання бойових завдань. До психологічних якостей можна віднести: стресостійкість, темперамент, відповідальність, мотивацію до діяльності, напрям стратегії стеження, рефлексивні обмеження, дисциплінованість, цілеспрямованість, комунікативні якості, мобільність, динамічність (гнучкість) мислення. При проведенні психофізіологічного моніторингу потрібно враховувати можливість формування емоційного вигорання та ознак розвитку ПТСР. Як було показано вище, оцінку більшості психологічних якостей операторів БпАК можна проводити 3 допомогою опитувальника NEO-FFI. Його застосування допоможе оцінити рівень низки особистісних якостей: нейротизм - рівень пристосованості і загальної емоційної стабільності особистості (включає підшкали: тривожність, злісна ворожість, депресія, рефлексія, імпульсивність, вразливість); екстраверсія - товариськість, гуманізм (включає підшкали: сердечність, товариськість, наполегливість, активність, пошук порушення активації, позитивні емоції); відкритість досвіду - активне відображення, естетична чутливість, увага до почуттів інших, перевага різноманітності, гнучкість розуму і незалежність в судженнях і оцінках (включає підшкали: фантазія, естетика, почуття, дії, ідеї, цінності); співробітництво - відображає особливості міжособистісної взаємодії (включає підшкали: довіра, чесність, альтруїзм, поступливість, скромність, чуйність); 
сумлінність - цілеспрямованість, рішучість і

прагнення до досягнень, самодисципліна, непохитність, 3 вираженими вольовими обдумування вчинків) [31, 32, 33, 34].

якостями (включає підшкали: компетентність, організованість, покірність обов'язку,

Класифікація внутрішніх та зовнішніх шкідливих чинників в професійній

Таблищя 1 діяльності особового складу пілотів БпАК

\begin{tabular}{|c|c|c|c|}
\hline $\begin{array}{l}\text { Чин- } \\
\text { ники }\end{array}$ & Клас & Підклас & Вид \\
\hline \multirow{3}{*}{ 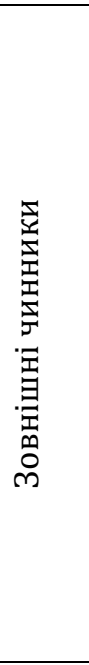 } & \multirow[t]{2}{*}{ 1. Незвичні } & Фізичної природи & $\begin{array}{l}\text { Електромагнітне випромінювання } \\
\text { Внутрішній мікроклімат } \\
\text { (освітлення, температурні фактори } \\
\text { тощо) } \\
\text { Моторна депривація }\end{array}$ \\
\hline & & Інформаційної природи & $\begin{array}{l}\text { Логічні } \\
\text { Компонентні } \\
\text { Ситуаційні обмеження функціону- } \\
\text { вання вибіркової уваги }\end{array}$ \\
\hline & 2. Інформаційні & $\begin{array}{l}\text { Недостатність інформації } \\
\text { Надмірність інформації } \\
\text { Помилковість інформації } \\
\text { Структурно-інформаційні } \\
\text { (подвійна діяльність) } \\
\text { Несподіваність інформації } \\
\text { Семантичні }\end{array}$ & $\begin{array}{l}\text { Фактори, які пов'язані з власною } \\
\text { структурою інформаційного потоку } \\
\text { Фактори комунікабельності } \\
\text { Міжгруповий конфлікт } \\
\text { Страх та паніка }\end{array}$ \\
\hline \multirow[b]{3}{*}{ 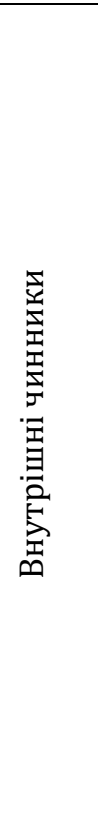 } & 1. Психофізіологічні & $\begin{array}{l}\text { Неадекватні значення } \\
\text { індивідуально- } \\
\text { психологічних та } \\
\text { психодинамічних якостей, } \\
\text { низький рівень } \\
\text { фізіологічних резервів } \\
\end{array}$ & $\begin{array}{l}\text { Психоемоційний стрес } \\
\text { Десинхроноз } \\
\text { Втрата зацікавленості, байдужість, } \\
\text { зниження обачності та пильності, } \\
\text { хронічна втома }\end{array}$ \\
\hline & $\begin{array}{l}\text { 2. Соціально- } \\
\text { психологічні }\end{array}$ & Колективна несумісність & $\begin{array}{l}\text { Індивідуальне самозбереження, що } \\
\text { нагадує колективні дії }\end{array}$ \\
\hline & 3. Медичні & Стан здоров’я & $\begin{array}{l}\text { Хвороби (особливо зорового } \\
\text { аналізатора, центральної нервової } \\
\text { системи) } \\
\text { Постійна стомленість без } \\
\text { навантаження, апатія, } \\
\text { дратівливість, втрата апетиту, біль } \\
\text { в ділянці серця. } \\
\text { Різке зниження показників } \\
\text { функціонального стану протягом } \\
\text { польоту, робочого дня (льотної } \\
\text { зміни), виражене протягом тижня, } \\
\text { місяця }\end{array}$ \\
\hline
\end{tabular}

До психофізіологічних якостей можна умовно віднести такі якості: концентрація, переключення, стійкість та розподілення уваги, схильність до розвитку стану монотонії, рівень емоційних, інтелектуальних та фізичних резервів організму оператора, швидкість прийняття рішень, працездатність та надійність діяльності [35], швидкість реакції (проста, складна зорово та слухомоторні реакції, реакція на рухомий об'єкт), обсяг оперативної пам'яті, сила, рухливість, динамічність, лабільність та врівноваженість нервових процесів, просторова уява, точність та координація рухів, адаптивність, поріг індивідуальної стійкості до зриву при дії стрес-факторів.

Наведені характеристики професійної діяльності пілотів БпАК звичайно потребують від людини наявності цілої низки відповідних професійно важливих якостей. Широкий аналіз джерел інформації у цій роботі дозволив виділити як професійно важливі якості, так і якості, які перешкоджають ефективності професійної діяльності оператора БпАК (табл. 2). 
Характеристика професійно важливих якостей пілотів БпАК

\begin{tabular}{|c|c|c|}
\hline Якості, що забезпечують успіш & іість виконання професійної & $\begin{array}{c}\text { Якості, що } \\
\text { перешкоджають } \\
\text { ефективності професійної } \\
\text { діяльності }\end{array}$ \\
\hline 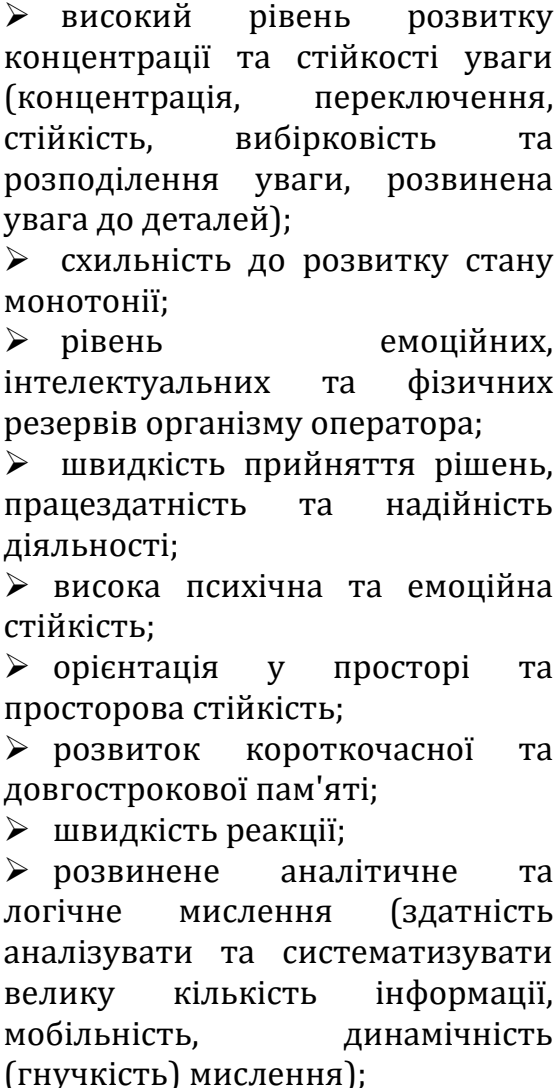 & 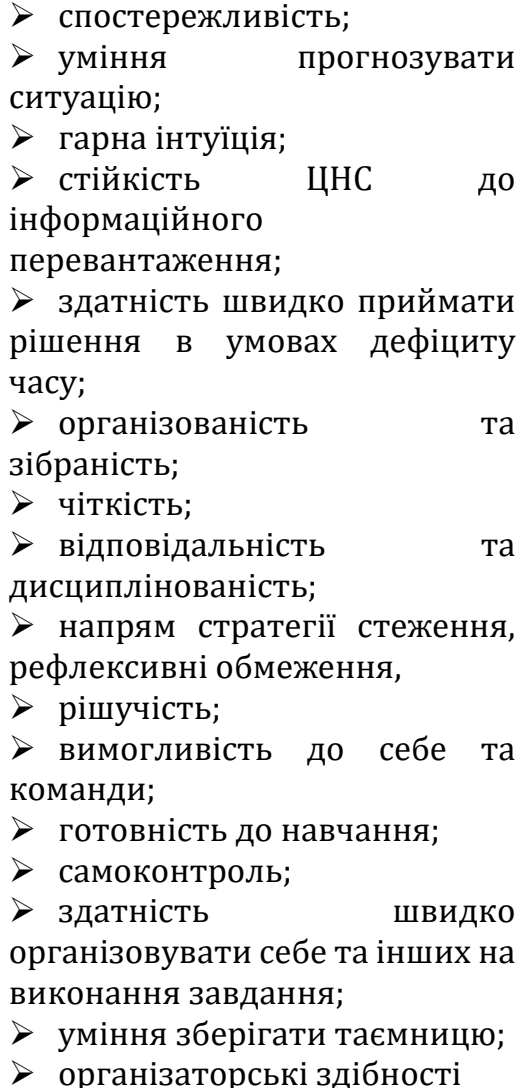 & $\begin{array}{l}>\text { нечесність; } \\
>\text { корисність; } \\
>\text { аморальність; } \\
>\text { неуважність; } \\
>\text { запальність; } \\
>\text { імпульсивність; } \\
>\text { неорганізованість; } \\
>\text { недисциплінованість; } \\
>\text { швидка стомлюваність; } \\
\text { > схильність до впливу } \\
\text { чужих; } \\
>\text { брутальність, } \\
\text { невихованість; } \\
\text { > безвідповідальність; } \\
>\text { нездатність } \\
\text { аналізувати, зіставляти } \\
\text { факти, робити висновки; } \\
>\text { нерішучість, ригідність. }\end{array}$ \\
\hline
\end{tabular}

Таким чином, проведено попередній аналіз літературних даних щодо визначення професійної придатності операторів БпАК. Отримано перелік психологічних та психофізіологічних показників, що можуть застосовуватися для визначення ступеня професійної придатності операторів. Звісно, цей перелік може використовуватися для визначення критеріїв професійної придатності. В результаті проведення цієї

\section{Висновки}

1. Проведено аналіз професійної діяльності операторів безпілотних авіаційних комплексів (БпАК) та визначено основні функціональні обов'язки та стрес-навантаження цих осіб. Запропоновано класифікацію внутрішніх та зовнішніх шкідливих чинників в професійній діяльності особового складу пілотів БпАК.

2. Виявлено та запропоновано перелік психологічних та психофізіологічних професійно важливих якостей пілотів БпАК, що забезпечують успішність виконання роботи перелік може бути скорочено i оптимізовано. Проте світовий досвід показує, що складна та відповідальна робота оператора БпАК потребує не тільки первинного відбору до цієї роботи, але й постійного моніторингу психофізіологічних характеристик оператора для збереження його здоров'я, забезпечення високої працездатності та надійності при виконанні бойових завдань, підвищення професійного довголіття.

професійної діяльності, та є необхідними для проведення професійного відбору персоналу з керування безпілотними авіаційними комплексами i моніторингу їx психофізіологічних якостей, а також якості, що перешкоджають ефективності професійної діяльності.

3. Визначено комплекс методичних засобів, використання яких сприятиме проведенню професійного психофізіологічного відбору операторів БпАК. 


\section{Література}

1. Pankok C., Bass E.J. A Decadal Revisiting of the Assessment of Pilot Control Interfaces for Unmanned Aircraft Systems. Materials of the annual meeting of the Society for Human Factors and Ergonomics. 2017. V. 61 (1). P. 63-67. https://doi.org/10.1177/1541931213601482

2. Петренко О.В. Психологічні аспекти новітніх підходів до забезпеченняефективності наземних екіпажівбезпілотних літальних апаратів. Актуальні проблеми психології: Збірник наукових праць Інституту психології імені Г.С. Костюка. К.: «ДП Інформаційно -аналітичне агентство», 2015. Т. Х. Вип. 27. С. $436-450$.

3. Пасічник B.I., Афанасенко В.С. Особливості професійного відбору кандидатів на посади операторів безпілотних авіаційних комплексів тактичних класів. Честь і закон. 2019. № 4 (71). С. 126136.

4. Wickens C., Dixon S., Ambinder M. Workload and Automation Reliability in Unmanned Air Vehicles. Advances in Human Performance and Cognitive Engineering Research. Human Factors of Remotely Operated Vehicles. 2006. V. 7. P. 209-222.

5. Cohn J.V., Olde B.A., Arnold R.D., O'Neill E.B. Military Unmanned Aircraft System Operators: Training and Human Performance. Issues Proceedings of the 17-th International Symposium on Aviation Psychology. Dayton (Ohio, USA): Right State University. 2013. P. 341-346.

6. Першлевич А. И., Бараева Е. И., Шлыкова Т. Ю. Психологическое обеспечение деятельности операторов беспилотных авиационных комплексов. Научные труды республиканского института высшей школы. 2020. № 20-3. С. 257-264.

7. Ударцева Т.Є. Доцільність проведення професійного добору операторів безпілотними літальними апаратами. Системи озброєння і військова техніка. 2016. № 1(45). С. 186-189.

8. Наказ МО України від 08.12.2016 № 661 «Про затвердження Правил виконання польотів безпілотними авіаційними комплексами державної авіації України» https://zakon.rada.gov.ua/laws/show/z0031-17\#Text

9. Наказ МО України від 30.09.2015 № 519 «Про затвердження Правил медичного забезпечення польотів державної авіації України» https://zakon.rada.gov.ua/laws/show/z1287-15\#Text

10. Сыпачев B.C., Михалёв А.А. Компетенции необходимые оператору беспилотных летательных аппаратов. Актуальные проблемы авиации $и$ космонавтики. 2018. Т. 3. С. 571-573.

11. https://russiandrone.ru/publications/evolyutsiyasistem-upravleniya-bespilotnykh-letatelnykh-apparatovot-poyavleniya-do-nashikh-dney-aerogeo/

12. Makarov, O., \& Titkov, O. (2014). Kak rabotayut operatory BPLA [How UAV's operators work]. Populyarnaya mekhanika - Popular Mechanics, 12 (146). : https://popmech.ru/weapon/53407-kak-rabotayutoperatory-bpla/

13. Сафонова А.В., Филоненко Л.В., Ковалев А.П. Учет психологических аспектов деятельности операторов беспилотных летательных аппаратов в подготовке будущих офицеров в военных вузах. Международный журнал психологии и педагогики в служебной деятельности. 2018. № 1. С. 100-106.

14. Chappelle W., McDonald K., Thompson B., Swearengen J. Prevalence of High Emotional Distress and Symptoms of Post-Traumatic Stress Disorder in U.S. Air Force Active Duty Remotely Piloted Aircraft Operators (2010 USAFSAM Survey Results). Report AFRL-SAWP-TR2013-0002. USAF School of Aerospace Medicine Aerospace Medicine Department/FECN 2510 Fifth St. WrightPatterson AFB, OH 45433-7913. Pp. 1-2. URL: http://www.ncbi.nlm.nih.gov/pubmed/25102551

15. Strawser B.J. (ed.) Killing by Remote Control: The Ethics of an Unmanned Military. NY: Oxford University Press; 2013. 296 p.

16. Кукушкин Ю.А., Айвазян С.А. Методика автоматизированной обработки управляющих движений оператора в прикладных исследованиях надежности эргатических систем. Кибернетика $u$ программирование. 2018. № 5. С.15-23.

17.Завалова Н.Д., Ломов Б.Ф., Пономаренко В.А. Образ в системе психической регуляции деятельности. М.: «Наука». 1986. 174 с.

18. Гордеева Н.Д. Экспериментальная психология исполнительного действия. М.: Тривола. 1995. 324 с.

19. Водлозеров В.М., Тарасов С.Г. Зрительнодвигательная активность человека в условиях слежения. Харьков: Изд-во Гуманитарный Центр. 2002. 242 c.

20.Ульман Ш. Принципы восприятия подвижных объектов. М.: Радио и связь. 1983. 168 с.

21. Савченко Е.В. Диагностика рефлексивных умений на метакогнитивном уровне рефлексивной компетентности. Вестник Пермского университета. 2015. Вып. 3(23). С. 97-108.

22. Суворов Н.Ф., Таиров О.П. Психофизиологические механизмы избирательного внимания. Л.: Наука. 1985. 287 с.

23. Медведев В.И. Устойчивость физиологических и психологических функций при действии экстремальных факторов. Л., 1982. 104 с.

24. Сыпачев В.С., Михалёв А.А. Компетенции необходимые оператору беспилотных летательных аппаратов. Актуальные проблемы авиации и космонавтики. 2018. Т. 3. С. 571-573.

25. Кичак В.М., Коваль Л.Г., Макогон В.I. Моделювання процесу відбору операторів дистанційнокерованих пристроїв із використанням нечіткої логіки. Наукові праці ВНТУ. 2020. № 3. С.

26. Hoffmann C.C., Hoffmann K.P., Kay G. The role that cognitive ability plays in CRM. Collaborative Crew Performance in Complex Operational Systems. 1998. P.37.137.22.

27. Kay G., Dolgin D., Wasel B., Langelier M., Hoffman C. Identification of the cognitive, psychomotor, and psychosocial skill demands of uninhabited combat aerial vehicle operators. Naval air warfare center report. - 1999. Retrieved 12Feb. 2012 from http://www.dtic.mil/cgibin/GetTRDoc?AD=ADA368578 
28. ДНАОП 0.03-8.06-94. Перелік робіт, де $\epsilon$ потреба у професійному доборі. - Режим доступу: http://zakon3.rada.gov.ua/laws/show/ru/z0018-95

29. Стасюк В. В. Військова психологія видородової діяльності: підруч. для слухачів та студ. вищ. навч. закл. Київ: Золоті ворота, 2012. 458 с

30. Першин Ю.Ю. Психоэмоциональные расстройства операторов БПАК (по материалам иностранных источников): презентацияпроблемы. Вопросы безопасности. 2017. № 3. С. 17-30.

31. Costa P, McCrae R, Martin T., Oryol V., Rukavishnikov A., Senin I. Personality development from adolescence through adulthood furthe cross- cultural comparisons of age differences. In Temperament and Personality Development across the life span. Edited by V.J.Molfese, D.L. Molfese , LEA, New Jersey, London, 2000. P.235-253.

\section{References}

1. Pankok, C., \& Bass, E. (2017). A Decadal Revisiting of the Assessment of Pilot Control Interfaces for Unmanned Aircraft Systems. Proceedings of the Human Factors and Ergonomics Society Annual Meeting, 61, 63 67. https://doi.org/10.1177/1541931213601482

2. Petrenko, O.V. (2015). Psychological aspects of the latest approaches to ensuring the efficiency of ground crews of unmanned aerial vehicles. Current problems of $\begin{array}{llll}\text { psychology, } & 10 & \text { (27), } & 436-450 .\end{array}$ http://nbuv.gov.ua/UJRN/appsuh 2015 10 27 43

3. Pasichnyk, V.I., Afanasenko V.S. (2019 Features of professional selection of candidates for the positions of operators of unmanned aerial vehicles of tactical classes. Honor and Law, 4 (71). 126-136. https://doi.org/10.33405/20787480/2019/4/71/197001

4. Wickens, C. D., Dixon, S. R., \& Ambinder, M. S. (2006). Workload and automation reliability in unmanned air vehicles. In N. J. Cooke, H. L. Pringle, H. K. Pedersen, \& O. Connor (Eds.), Advances in human performance and cognitive engineering research (Vol. 7). Human factors of remotely operated vehicles . 209-222. Elsevier. $\underline{3601(05) 07015-3}$

https://doi.org/10.1016/S1479-

5. Cohn, J.V., Olde, B.A., Arnold, R.D., O'Neill, E.B. (2013). Military Unmanned Aircraft System Operators: Training and Human Performance. Issues Proceedings of the 17-th International Symposium on Aviation Psychology. 341-346.

https://corescholar.libraries.wright.edu/isap 2013/58

6. Pershlevich, A. I., Baraeva, E. I., Shlykova, T. Yu. (2020). Psychological support of the activities of operators of unmanned aerial complexes. Scientific works of the republican institute of higher education. 20-3. C. 257264.

7. Udartseva, T.E. (2016). Expediency of professional selection of drone control operators. Weapons systems and military equipment, (1), 186-189..

8. Order of the Ministry of Defense of Ukraine dated 08.12.2016 № 661 "On approval of the Rules of flight operations by unmanned aerial vehicles of the state
32. Costa P.T., McCrae R.R. Revised NEO Personality Inventor)' (NEO PI-R) and NEO Fife -Factor Inventory (NEO- FFI). Professional Manual. Psychological Assessment Resources, Inc. P.O. Box 998. Odessa, Florida,1992. 101 p.

33. Costa P.T., McCrae R.R. The Five-Factor Model of Personality and Its Relevance to Personality Disorders.. Journal of Personality Disorders, 1992. № 4. P. 343-371.

34. John O.P. The "Big Five" factor taxonomy: Dimensions of Personality in the natural language and questionnaires. In Handbook of personality theory and research. Edited by L.Pervin. New York: Guilford, 1990. P. 66-100.

35. Кальниш В.В., Швець А.В. Працездатність та надійність напруженої операторської діяльності: механізми формування та методи оцінки: Монографія. Вінниця. «ПП Балюк І.Б.», 2019. 352 с. ISBN 978-9662696-57-8.

aviation of

Ukraine" https://zakon.rada.gov.ua/laws/show/z0031-17\#Text

9. Order of the Ministry of Defense of Ukraine dated 30.09.2015 № 519 "On approval of the Rules of medical support of flights of state aviation of Ukraine"https://zakon.rada.gov.ua/laws/show/z128715\#Text

10.Sypachev, V.S., \& Mikhalev, A.A. (2018). The competencies required for an unmanned aerial vehicle operator. Actual problems of aviation and astronautics, $3(4$ (14)). 571-573.

11.https://cyberleninka.ru/article/n/kompetentsiineobhodimye-operatoru-bespilotnyh-letatelnyhapparatov/pdf

12. https://russiandrone.ru/publications/evolyutsiya -sistem-upravleniya-bespilotnykh-letatelnykhapparatov-ot-poyavleniya-do-nashikh-dney-aerogeo/

13. Makarov, O., \& Titkov, O. (2014). Kak rabotayut operatory BPLA [How UAV's operators work]. Popular Mechanics, 12 (146). https://popmech.ru/weapon/53407-kak-rabotayutoperatory-bpla/

14.Safonova, A.V., Filonenko, L.V., \& Kovalev, A.P. (2018). Taking into account the psychological aspects of the activities of operators of unmanned aerial vehicles in the training of future officers in military universities. International Journal of Psychology and Pedagogy in Service Activity, (1), 100-106.

15. Chappelle, W. L., McDonald, K. D., Prince, L., Goodman, T., Ray-Sannerud, B. N., \& Thompson, W. (2014). Symptoms of psychological distress and posttraumatic stress disorder in United States Air Force "drone" operators. Military medicine, 179(8 Suppl), 6370. https://doi.org/10.7205/MILMED-D-13-00501

16. Strawser, B. J., \& McMahan, J. (2013). Killing by remote control : the ethics of an unmanned military. 296

17. Kukushkin Yuri Alexandrovich, \& Ayvazyan Sergey Albertovich (2018). Technique of automated processing of operator's control movements in applied research of the reliability of ergatic systems. Cybernetics and Programming, (5), 15-23. 
18. Zavalova, N.D., Lomov, B.F., Ponomarenko, V.A. (1986). Image in the system of mental regulation of activity. M .: "Science".174.

19. Gordeeva, N.D. (1995). Experimental psychology of executive action. $M$.: Trivola, 324.

20. Vodlozerov, V.M., Tarasov, S.G. (2002). Visualmotor activity of a person in conditions of tracking. Kharkiv: Humanitarian Center Publishing House, 242.

21. Ulman, S. (1983). The principles of perception of moving objects. M .: Radio and communication, 168.

22. Savchenko Elena Vyacheslavovna (2015). Diagnostics of reflexive skills at the metacognitive level of reflective competence. Perm University Bulletin. Philosophy. Psychology. Sociology, (3 (23)), 97-108.

23. Suvorov, N.F., Tairov, O.P. (1985) Psychophysiological mechanisms of selective attention. L.: Science. 287.

24. Medvedev, V.I. (1982). Stability of physiological and psychological functions under the influence of extreme factors. L., 104.

25. Kychak, V.M., Koval, L.G., \& Makogon, V.I. (2020). Simulation of the process of selection of operators of remote-controlled devices using fuzzy logic. Scientific works of Vinnytsia National Technical University, (3).

26. Hoffmann, C.C., Hoffmann, K.P., Kay, G.G. (1998) The role that cognitive ability plays in CRM. Paper presented at NATO Symposium, Human Factors \& Medicine Panel on Collaborative Crew Performance in Complex Operational Systems, Edinburgh, Scotland. 37.137.22.

27. Kay, Gary \& Dolgin, D. \& Wasel, B. \& Langelier, M. \& Hoffman, C.. (1999). Identification of the Cognitive, Psychomotor, and Psychosocial Skill Demands of Uninhabited Combat Aerial Vehicle (UCAV) Operators. Naval air warfare center report. 30. 16 http://www.dtic.mil/cgibin/GetTRDoc?AD=ADA368578
28. DNAOP 0.03-8.06-94. List of works where there is a need for professional selection. https://zakon.rada.gov.ua/laws/show/ru/z001895?lang=en\#Text

29.Stasiuk, V.V. (2012). Military psychology of postpartum activity: textbook. for students and students. higher textbook lock Kyiv: Zoloti Vorota, 458.

30.Pershin, Yu.Yu. (2017). Psycho-emotional disorders of UAVs' operators (based on foreign sources): presentation of the problem. Security issues. 3, 1730https://doi.org/10.25136/2409-7543.2017.3.23194

31. Costa, P. T., Jr., McCrae, R. R., Martin, T. A., Oryol, V. E., Senin, I. G., Rukavishnikov, A. A., Shimonaka, Y., Nakazato, K., Gondo, Y., Takayama, M., Allik, J., Kallasmaa, T., \& Realo, A. (2000). Personality development from adolescence through adulthood: Further cross-cultural comparisons of age differences. In V. J. Molfese \& D. L. Molfese (Eds.), Temperament and personality development across the life span, .235-253.

32. Costa, P. T., \& McCrae, R. R. (1992). Revised NEO personality inventory (NEO-PI-R) and Neo five-factor inventory (NEO-FFI). Psychological Assessment Resources, 101.

33. Costa, P.T., McCrae, R.R. (1992). The Five-Factor Model of Personality and Its Relevance to Personality Disorders. Journal of Personality Disorders, 4, 343 -371. https://doi.org/10.1521/pedi.1992.6.4.343

34. John, O. P. (1990). The "Big Five" factor taxonomy: Dimensions of personality in the natural language and in questionnaires. In L. Pervin (Ed.), Handbook of personality: Theory and research (pp. 66-100). New York: Guilford Press.

35. Kalnysh, V.V., Shvets, A.V.(2019). Working capacity and reliability of intense operator activity: mechanisms of formation and evaluation methods: Monograph. Vinnytsia. "Balyuk IB", 352. ISBN 978-966-2696-57-8.

\title{
ХАРАКТЕРИСТИКА ДЕЯТЕЛЬНОСТИ ВНЕШНИХ ПИЛОТОВ БЕСПИЛОТНЫХ АВИАЦИОННЫХ КОМПЛЕКСОВ И ИХ ПРОФЕССИОНАЛЬНО ВАЖНЫЕ КАЧЕСТВА: ТЕОРЕТИКО-ПРАКТИЧЕСКИЕ АСПЕКТЫ
}

\section{В.В. Кальниш ${ }^{1}$, А.В. Швец ${ }^{1}$, С.Н. Пашковский ${ }^{2}$}

\author{
1 Украинская военно медицинская академия, г. Киев, Украина. \\ 2 Военно-медицинский клинический центр Центрального региона, г. Винница, Украина
}

Актуальность. Имеющаяся информация о профессиональных требованиях к операторам беспилотных авиационных комплексов (БпАК) и их психофизиологических качеств, позволяющих выполнять управление этими комплексами в обычных и экстремальных ситуациях, является ограниченной, разрозненной и несистематизированный. Все эти причины стимулируют детальную разработку и уточнение перечня профессионально важных качеств и психофизиологических критериев профессиональной пригодности операторов БпАК необходимых для успешного осуществления своей деятельности.

Целью данной работы является поиск в современной литературе переченя профессионально важных качеств операторов БпАК и адекватных методов проведения профессионального психофизиологического отбора.

Материалы и методы. $C$ использованием методов системного, библиосемантичного и ретроспективного анализа изучено научные публикации о перечне профессионально важных качеств операторов БпАК и адекватных методов проведения профессионального психофизиологического отбора. Для этого осуществлен поиск доступных источников информации с 1982 по 2020 годы, касающиеся 
характеристик профессиональной деятельности операторов беспилотных летательных аппаратов, беспилотных авиационных комплексов, дронов. Изучали характеристики деятельности внешних пилотов беспилотных авиационных комплексов и их профессионально важные качества. На основе имеющихся данных были обобщены классификация внутренних и внешних вредных факторов в профессиональной деятельности личного состава пилотов БпАК и характеристики их профессионально важных качеств, которые были изложены в доступных публикациях.

Результаты. Проведен предварительный анализ литературных данных по определению профессиональной пригодности операторов БпАК. Предложено обобщенный перечень психологических и психофизиологических показателей, которые могут применяться для определения степени профессиональной пригодности операторов. Этот перечень может использоваться для определения критериев профессиональной пригодности. Мировой опыт показывает, что сложная и ответственная работа оператора БпАК требует не только первичного отбора $к$ этой работе, но и постоянного мониторинга психофизиологических характеристик оператора для сохранения его здоровья, обеспечения высокой работоспособности и надежности при выполнении боевых задач, повышения профессионального долголетия.

Выводы. Проведен анализ профессиональной деятельности операторов беспилотных авиационных комплексов (БпАК) и определены основные функциональные обязанности и стресс-нагрузки этих лиц. Предложена классификация внутренних и внешних вредных факторов в профессиональной деятельности личного состава пилотов БпАК. Выявлен и предложен перечень психологических и психофизиологических профессионально важных качеств пилотов БпАК, обеспечивающий успешность выполнения профессиональной деятельности, и необходимый для проведения профессионального отбора персонала по управлению беспилотными авиационными комплексами и мониторинга их психофизиологических качеств, а также качества, препятствующие эффективности профессиональной деятельности. Определен комплекс методических средств, использование которых будет способствовать проведению профессионального психофизиологического отбора операторов БпАК.

Ключевые слова: профессионально важные качества, профессиональная деятельность, внешние пилоты, беспилотный авиационный комплекс.

\title{
CHARACTERISTICS OF ACTIVITIES OF EXTERNAL PILOTS OF UNMANNED AIRCRAFT SYSTEMS AND THEIR OCCUPATIONALLY IMPORTANT QUALITIES: THEORETICAL AND PRACTICAL ASPECTS
}

\author{
V.V. Kalnysh'1, A.V. Shvets' ${ }^{1}$ S.M. Pashkovsky² \\ ${ }^{1}$ Ukrainian Military Medical Academy, Kyiv, Ukraine \\ ${ }_{2}^{2}$ Military Medical Clinical Center of the Central Region, Vinnytsia, Ukraine
}

Introduction. The available information on the occupational requirements for operators of unmanned aircraft complexes (systems) (UAS) and their psychophysiological qualities that allow them to operate these vehicles in normal and extreme situations is limited, fragmented and unsystematic. All these reasons stimulate the detailed development and refinement of the list of occupationally important qualities and psychophysiological criteria for the occupational suitability of unmanned aerial vehicles (UAVs) pilots required for the successful performance of their activities.

The purpose of this work is to search in the modern literature for a list of occupationally important qualities of UAV pilots and adequate methods of occupational psychophysiological selection.

Materials and methods. Using the methods of systematic, bibliosemantic and retrospective analysis, scientific publications on the list of occupationally important qualities of UAS, UAVs pilots and adequate methods of occupational psychophysiological selection have been studied. For this, a research was made for available sources of information from 1982 to 2020, which concerned the characteristics of the occupational activities of operators of unmanned aerial vehicles, unmanned aircraft complexes (systems), drones. The characteristics of the activity of external pilots of UAVs and their occupationally important qualities have been studied. The classification of internal and external harmful factors in the occupational activities of the personnel of UAVs pilots and the characteristics of their occupationally important qualities, which were mentioned in the available publications have been generalized.

Results. A preliminary analysis of the literature data to determine the occupational suitability of UAV pilots. A generalized list of psychological and psychophysiological indicators that can be used to determine the degree of occupational suitability of such pilots is proposed. This list can be used to determine eligibility criteria. World experience shows that the complex and responsible work of UAVs pilots requires not only the initial selection for this work, but also constant monitoring of psychophysiological characteristics of them to maintain their health, ensure high efficiency and reliability in combat missions, increase occupational longevity.

Conclusions. An analysis of the occupational activities of operators of UAVs pilots and identified the main functional responsibilities and stress of these individuals. The classification of internal and external harmful factors in the occupational activity of the personnel of UASs pilots has been offered. The list of psychological and psychophysiological occupationally important qualities of UAVs pilots that ensure the success of occupational 
activities and are necessary for occupational selection of personnel for the management of unmanned aerial vehicles and monitoring of their psychophysiological qualities, as well as qualities that hinder the effectiveness of occupational activities. A set of methodological tools for performance of occupational psychophysiological selection of UASs pilots has been identified. systems.

Key words: occupationally important qualities, occupational activity, external pilots, unmanned aircraft

Конфлікт інтересів: відсутній.

Conflicts of interest: authors have no conflict of interest to declare.

Відомості про авторів:

Кальниш В. В., в, С,D д-р біол. наук, професор, професор кафедри авіаційної, морської медицини та психофізіології Української військово-медичної академії, м. Київ.

Швець А. В., A, C, D, E, F полковник медичної служби, д-р мед. наук, старший науковий співробітник, заступник начальника Української військово-медичної академії з наукової роботи, м. Київ,

Пашковський C.M., в, C, D, полковник медичної служби, к-т мед. наук, начальник Військово-медичного клінічного центру Центрального регіону, м. Вінниця

$A$ - концепція та дизайн дослідження; $B$ - збір даних; $C$ - аналіз та інтерпретація даних;

$D$ - написання статmi; $E$ - редагування статmi; F- остаточне затвердження статті.

\section{Сведения об авторах:}

Кальниш В. В., д-р биол. наук, проф., профессор кафедры авиационной морской медицины и психофизиологии Украинской военно-медицинской академии. г. Киев.

Швец А. В., полковник медицинской службы, д-р мед. наук, старший научный сотрудник, заместитель начальника Украинской военно-медицинской академии по научной работе, г. Киев.

Пашковский С. Н., полковник медицинской службы, к-т мед. наук, начальник Военно-медицинского клинического центра Центрального региона, г. Винница.

\section{Information about authors:}

Kalnysh V. V., B, c, D DSc Biol., Prof., Professor of the Department of Aviation, Marine Medicine and Psychophysiology of the Ukrainian Military Medical Academy, Kyiv, https://orcid.org/0000-0002-5033-6659

Shvets A. V., A, C, D, E, F Col. MS, MD, DSc, Senior Researcher, Deputy chief of Ukrainian Military Medical Academy for sciense, Kyiv, E-mail: shvetsandro@gmail.com, https://orcid.org/0000-0002-9461-7129

Pashkovsky S. M. B, C, D, Col. MS, MD, PhD, Head of the Military Medical Clinical Center of the Central Region, Vinnytsia.

$A$ - research concept and design; $B$ - collection and/or assembly of data; $C$ - data analysis and interpretation;

$D$ - writing the article; $E$ - critical revision of the article; $F$ - final approval of the article.

Адреса для листування: вул. Московська, 45/1, буд. 33, м. Київ 01015 